\title{
Tayub Dance within the Realm of Karo Ritual of Ngadas Village Tenggerese
}

\author{
M A Nurmansyah ${ }^{1}$, F N Setiawan. ${ }^{2}$, S V Eka ${ }^{3}$, R Nufiarni ${ }^{4}$. \\ 1,2, $3,{ }^{4}$ Universitas Brawijaya, Malang, Indonesia \\ \{1andhyfib@ub.ac.id, ${ }^{2}$ fredyns@ub.ac.id, ${ }^{3}$ scarletina@ub.ac.id, ${ }^{4}$ nufiarni_rizki@ub.ac.id \}
}

\begin{abstract}
Karo ritual was performed differently by Tenggerese in Ngadas; they inserted Tayub dance within the sacred ritual. Thus, this article aims at examining the "newly-structured" Karo ritual performance and interpreting its function for millennials in the Tenggerese inner circle. Also, this article pictures the role of the ritual for other people from different cultural backgrounds living side by side with the Tenggerese. Through an in-depth interviewing data collection and non-participatory observation, it is found that the "hybrid," the mixture of Karo and Tayub dance, is used as a medium of value negotiation among generations involved in the ritual. It also demonstrates a conformity strategy of Tenggerese in Ngadas who try to live inclusively in the landscape of different cultural groups. Therefore, the "hybrid" is understood as ritual performance management designed by Tenggerese in Ngadas due to its position to the inner and outer circles of the community.
\end{abstract}

Keywords: Tayub Dance, Hybrid-design, Aesthetic Negotiation, Conformity Strategy, The Inner/outer Circle

\section{INTRODUCTION}

Karo ceremony, for Tenggerese, is one of two major annual traditions that is held in the second month of the Tengger calendar. The ceremony begins in the mid of the second month, which is marked by the performance of Sodor Dance and ends at the end of the month, which is marked by the performance of Ujung Dance [1] (Setiawan, Nurmansyah, Nufiarni, \& Eka, 2018). In brief, the structure of the ceremony is following the explanation from Dukun Pandita (Priest) Keto, Ketua Paruman Brang Kulon (Chief of Tenggerese Priests Community from West Hemisphere), as follows.

"Karo dimulai pada pertengahan bulan kedua kalender Tengger (tanggal 17 di Brang Kulon dan tanggal 18 di Brang Wetan) dengan Tari Sodor. Setelah Tari Sodor, dilakukan pemantraan Dandanan dan penyimpanan kembali Jimat Klonthong, yang sehari sebelumnya diambil dari penyimpanannya. Prosesi sodoran selesai, Dukun mulai berkeliling rumah warga satu persatu untuk melaksanakan upacara, yaitu memberikan sesajen kepada leluhur. Ritual Karo diakhiri dengan Tari Ujung di desa Wonokitri, dimana para penari bertelanjang dada dan kemudian saling memukul satu sama lain dengan rotan." [2] 
("Karo starts in the mid of the second month of the Tengger calendar, on the 17th at Brang Kulon (West Hemisphere) and the 18th at Brang Wetan (East Hemisphere), with Sodor Dance. After the dance, the priest casts a spell on the offerings and restore Klonthong Talisman, which was taken out from its former place the day before. When the procession of Sodor dance is complete, the priest begins to visit each of the Tenggerese' houses to carry out a ceremony, namely giving offerings to the ancestors. Karo ritual ends with Ujung Dance performed in Wonokitri village, where the dancers are bare-chested and then hit each other with rattan".)

As a ritual, the structure of the Karo ceremony is carefully kept to remain sacred. It serves as a remembrance of famous folklore believed by Tenggerese, the story of Ajisaka and his loyal subordinates, Setia and Setuhu. Like other rituals, the Karo ceremony is repetitive and highly controlled by Tenggerese priests; it is conducted every year and has never been performed for other purposes but a spiritual practice. Its formulaic nature is in line with the concept of ritual explained by Sims and Stephen, that rituals "are repeated, habitual actions, but they are more purposeful than custom; rituals are often highly organized and controlled." In this case, Karo a high-context ritual for it is "very stylized and occur at set times for specific, announced purposes" [3]. The consistency of the pattern is one of the efforts to present the doctrine of sacredness at the ritual so that the ritual bearers "are persuaded to believe that the values are indeed real, true values the group holds" [3]. Tenggerese understands and believes that the existence of patterned structures of the ritual plays an essential role in the success of their life journey.

Although Keto claimed that the structure and the practice of Karo ritual are highly exclusive, research observations of the ritual conducted in Ngadas in 2017, a Tenggerese village in Malang Regency, showed differently. The difference was in the performance at the ritual opening. Tayub dance was performed in the opening of Karo in Ngadas replacing Sodor dance, which is claimed to be performed at the beginning of the ritual.

Tayub or Tayuban is rooted in a spiritual conception that relates to the belief in Dewi Sri. She is a mythological deity who controls food [4] ), in this case is a Javanese staple food, rice. As an embodiment of Javanese people religiosity, Tayub dance is an aesthetic expression presented by farmers so that they are free from various calamities because Dewi Sri likes all traditional arts. Tayub dance is presented by female dancers, commonly called tandak, who dance in pairs with pengibing (male dancers). The dance is performed in many regions of Java. In East Java, the dance is known in several areas such as Tuban, Nganjuk, Lamongan, Blitar, Kediri, Probolinggo, and Jember. The once mystical dance has shifted into popular entertainment presented on various occasions. Sawer or saweran, a sum of money given to the tandak by any male audience who joins in dancing with her and serves as pengibing, has become dominant in Tayub performance. This has consequently reduced the ritualistic value of the dance.

It turns out that Tayub dance which is popular among East Javanese people has even influenced the sacred ritual of Karo in Ngadas village. The presence of Tayub dance results in the modification of the Tenggerese sacred ritual structure. This modification is interesting to study, especially about cultural intersection and negotiation between Javanese and Tenggerese cultures. At this point, cultural hybridization seems to affect the change of Karo ritual in the form of the transculturation process. The concept of hybridization, according to Ashcroft, can be understood as "the ongoing condition of all human cultures, which contains no zones of purity because they undergo continuous processes of transculturation" [5]. Two important 
keywords from Ashcroft's argument, "no zones of purity" and "transculturation," underlie the existence of cultural hybridization. Furthermore, the hybridization can be understood as a symptom that indicates the merging of two different cultures that has resulted in something new or provided a new element so that it can be accepted by the community at a certain time. Young explained that "Hybridity thus makes a difference into sameness, and sameness into difference, but in a way that makes the same no longer the same, the different no longer simply different" [5].

The difference between the performance structure of Karo ritual in Ngadas village and the same ritual in other Tenggerese villages can be seen as an attempt to conduct negotiations in terms of cultural values. The exciting aspects to be explored further are what cultural values that are being negotiated to whom it is intended, and why the negotiations are needed.

\subsection{Research Method}

This research is qualitative descriptive research. This research uses two types of data, namely primary and secondary data. Primary data about the Karo ritual are taken from Tenggerese in Ngadas village, Malang Regency and collected by ethnographic methods. Secondary data are in the form of related information about the Tenggerese and Karo ritual in the form of books, scientific articles, and research reports.

Primary data was collected using in-depth interviews with Tenggerese priests and some community members and non-participant observations. The collected data are categorized based on thematic groups made by researchers by looking at the findings in the field and the results of document studies. The categorization is directed at the three issues mentioned in the focus of the study, namely what cultural values that are being negotiated, to whom the negotiations are intended, and why the negotiations are needed.

The analysis will be carried out on the data that have been codified by employing Functionalism Approach proposed by William R. Bascom (1965). As quoted by Sims and Stephen, Bascom identified four folklore functions, namely educating, escaping accepted limitations of our culture, maintaining cultural identity, and validating existing cultural norms [3]. Referring to these concepts, the negotiated forms that occur in the performance structure of Karo ritual in Ngadas village will be described thoroughly.

\subsection{Result and Discussion}

The structure of the Karo ritual has been passed down from generation to generation in Tengger. The performance of Sodor dance is a must because this dance marks the beginning of the ritual. Tomo, Ketua Paruman Brang Wetan (the Chief of Tenggerese Priests Community from East Hemisphere) and a priest from Ngadisari village, said that the performance of the dance is intended to be a reminder for Tenggerese about the origin of human life. The dance consists of twelve dancers who are carrying and swinging bamboo containing seeds grown in Tengger land while dancing. The scene when they break the bamboo (by hitting it to the floor) and let the seeds scattered all over the stage at the end of the dance is a symbol of humans' origin and birth on earth. In other words, the performance of Sodor dance during Karo ritual brings an essential message about the philosophy of life believed by Tenggerese throughout generations [6]. It is this philosophy that is celebrated through the dance.

Referring to the aforementioned information, the performance of Karo ritual in Ngadas, which eliminates Sodor dance in its structure, is an interesting "statement" regarding the 
identity of the Tenggerese in the village. Replacing Sodor with Tayub is a major shift. It becomes a distinctive feature and, certainly, contains certain propositions. It indicates the long believed values about the Karo ritual have been modified from its being exclusively dogmatic and sacred in the constellation of Tenggerese traditional life in Ngadas. To understand the differences between Sodor and Tayub, the following Table 1 shows the comparison between the elements of the two dances.

Table 1. Comparison between the elements of Sodor and Tayub dance

\begin{tabular}{lll}
\hline Entity & Sodor & Tay $\boldsymbol{u b}$ \\
\hline Domain & Elite & Folk \\
Form & Mythic-Simbolic & Profane-Literal \\
Communication Level & One-way & Two-way \\
Nature & Close & Open \\
Ideological Value & Sacred & Sacred/Spiritual \\
Genealogy & Tengger & Java \\
\hline
\end{tabular}

Comparing the above elements, Sodor and Tayub have the same ideological value, namely sacred or spiritual. Sodor is sacred because this dance functions as a reminder of the origin of human presence on earth whereas Tayub is more dominant in "spirituality" because its value reflects the pattern of micro and macro cosmos relations. In terms of values, replacing Sodor with Tayub in Karo does not mean dragging the ritual out to secular entertainment. The ritual remains sacred for Tenggerese. However, the change in structure means certain elements in the ritual are compromised.

The insertion of Tayub in Karo ritual potentially constructs a cultural hybrid. The sacred value of Karo is not lost, but there are parts of the ritual that are shifted to become secular because some features are changed in the course of the ritual. One of the new features replacing the previous one comes from a different domain, where the new feature is in the "folk" domain. Consequently, Karo in Ngadas is not an elitist ritual. Since Tayub has become a favorite show among the Javanese people from various cultural backgrounds, its construct adjusts to populist demands in a performative context. Therefore, particular preconditions or ceremonial preparations which are previously sacred to present the opening dance for Karo do not exist anymore. This is because Tayub is a form of social dance and entertainment that belongs to all people (folk).

Tayub is manifested in a more profane-literal form and does not imply mystical-symbolic content. The reason is Tayub dancers perform spontaneous movements; there is no uniformity or structured patterns. The movements are performed arbitrarily and are only intended to enjoy the accompaniment of music. On the other hand, movements in Sodor dance are arranged purposely (although the pattern of movements is not complex) so that it can be performed simultaneously by twelve dancers. Not to mention that some mystical-symbolic movements are presented to emphasize the sacredness of the dance such as the bamboo movement and the spread of seeds inside the bamboo. In the interactional context, Tayub makes Karo ritual in Ngadas more communicative due to the presence of pengibing, the male dancers. Although they are selected and chosen from the respected community leaders, it is clear that their presence in the dance has made the ritual more interactive. On the other hand, Sodor dance does not allow audience involvement and direct interaction with the audience during its procession. The dancers have been prepared in advance, chosen, and trained long before the performance. They are exceptional performers who carry out the sacredness of the opening 
ceremony of the ritual. All in all, Tayub is open and accommodating to the audience, the people, while Sodor is carefully preserved and exclusive.

The change from Sodor to Tayub has changed the nuance of the ritual from the sacred to the secular. Nevertheless, the presence of this new feature does not mean that Karo sacredness has been lost. Looking at all the preparations for the activities, the implementation of the activities, and the end of the activity, it is clear that Karo which is opened by Tayub remains a sacred and meaningful ceremony. The ceremony, as "a series of special actions have rules and special means to carry them out" [7], is still visible in the ritual and is still very special for the ritual bearers. Then, what about the issue of authenticity? Further discussion about this issue will answer the second and third focus of the study in this article.

In tradition, which serves as a medium of communication and group identity, authenticity becomes less of concern. Authenticity depends on how certain community groups use the tradition they have [3]. The tradition that was initially understood as a "text" that was independent of the context has turned functions into "texts" which must be understood in the context of its communication. At this point authenticity becomes dynamic, adjusting to how members of a community use the tradition together at a particular historic moment for their communication media. This occurs in the Karo ritual in Ngadas. However, instead of discussing more its authenticity, this article will focus on to who changed feature in the ritual is intended and why the change should be done. If the presence of the ritual is in the context of communication medium, then the interesting question is to whom the ritual, with its hybrid construct, is intended?

From the results of data collection in the field, Karo ritual in Ngadas is a medium of communication of Tenggerese identity for both its community members (the inner circle) and also other community groups (the outer circle) which have different cultural bases. The interesting finding regarding ritual as a communication medium of group identity for its members is related to the educational function of cultural values as described by Bascom. The hybrid construction of the ritual functions as education of cultural values that are not only historical but also diachronic and correlated with values in contemporary society.

Cultural change or cultural transformation can be influenced by several factors, namely (1) contact with other culture, (2) advanced education system, (3) respect for attitude of someone's work and passion for achievement, (4) tolerance toward diverge attitude, (5) open society system, (6) dissatisfaction, (7) future orientation, (8) increasing point of living standard [8]. Referring to those factors, the change in Karo ritual in Ngadas is in line with points $1,4,6$ and 7 .

The presence of Tayub as "a new feature" in Karo ritual is influenced by the fluidity of cultural interactions that occur between Tenggerese and other community groups in Ngadas village. Intense interaction among cultural members with the support of various communication media is very likely to form double consciousness. As stated by Tyson, a "double consciousness or double vision, ..., a consciousness or a way of perceiving the world that is divided between two antagonistic cultures" [9]. In the case of Tenggerese in Ngadas, however, is a bit different. Double consciousness is characterized by a reluctance to stick on patterns and values of standardized and doctrinal inheritance. Thus, innovating traditions, including rituals, is not taboo as long as it is believed to present the cultural identity of the ritual bearers still and become a common commitment. Relationships with other cultures because of open cultural interactions result in "dissatisfaction" in the existing culture to that innovation is inevitable.

In the context of the Tenggerese in Ngadas village, they have been in intense contact with various cultural groups outside the Tengger culture. Demographic factors support this 
situation. Based on observations and interviews in the field, Tenggerese in Ngadas were exposed to Javanese values more intensely than the Tenggerese in other regions. Contact with a variety of other cultural aspects, such as religion (the Tenggerese priest in Ngadas is a Buddhist), and exposure of Javanese cultural values in daily life becomes the cause of hybridity which enables the merging of two cultural features, Tenggerese, and Javanese. In its function as a medium of education of Tengger values, this hybrid becomes a strategy to maintain the Tengger values in contemporary society. One of the informants said that "the change does not violate the essence of Karo in its ceremonial offerings" [10]. In other words, the change of feature does not eliminate the values contained in Karo; it is even able to preserve the existence of the ritual in the contemporary cultural landscape.

The hybridity is an effective negotiation strategy to safeguard the tradition's value for the next generation. The continuity of this ceremony is important for educational purposes aimed at the inner circle of the community, even though it must be transformed accordingly. In short, in an open society system, being tolerant of different cultural perspectives is deemed necessary for Tenggerese authorities in Ngadas village to preserve the values of Tengger.

When the performance of Tayub was juxtaposed with other forms of people's entertainment such as Campursari (a kind of popular Javanese folk music), there was a firm statement from a Tenggerese priest who said that, "the element of entertainment is not included in the Karo ritual, and it belongs to the youth only" [10]. It is a statement that clarifies the safeguards over the sacredness of the Karo ritual. It is clear that replacing Sodor dance with Tayub dance is a cultural embodiment to maintain the sacredness of the value of the ritual itself. Therefore, Tayub cannot be replaced by Campursari, which is considered merely as an entertainment enjoyed by the younger generation. This statement emphasizes that openness to changes in the Karo ritual is limited and not carelessly carried out by the Tenggerese authorities in Ngadas. Tayub is seen as a possible change because it does not eliminate the value of sacredness/spirituality in the ritual.

In addition to having an educational function, the existence of a new feature in the Karo ritual in Ngadas aims at guarding cultural conformity so that its presence acceptable in diverse communities. Tenggerese in Ngadas village is perceptive with the presence of Javanese communities in their neighborhood by inserting a type of Javanese cultural manifestation in the form of Tayub. The insertion of Tayub is not only a hybrid marker but also a "cultural language" which can be understood by other cultural groups living side by side in Ngadas. The reasons why Tayub is chosen among other forms of Javanese traditional arts can be described below.

The first reason synthesized from the discussion with the informants in Ngadas is because of the identical performance between Sodor and Tayub, which are both performed by a group of dancer. Both dances are performed by many people in pairs even though in the case of Sodor only male dancers allowed. Another aspect that makes Tayub acceptable is because the moves in the dance are not complicated. Although the dance movement in Sodor is not as free as the dance movement performed in Tayub, the simultaneous movements being performed are relatively simple which does not require special skills. The second reason is that Tayub is chosen because of its socio-cultural factors. It is considered capable of presenting space for the spectators during the performance. It is possible for each member of the community to be actively involved in the Tayub to make it popular to be used as a substitute for Sodor, which does not allow the involvement of the audience.

In addition to the reasons mentioned above, an ideological factor is another important reason why Tayub dance is chosen. It is a political, ideological factor that serves as a defense strategy. Tenggerese in Ngadas occupy limited space in the complexity of demographic 
aspects in the village. Javanese ethnic group and non-Tengger Hindu religions occupy the dominant area in Ngadas. In such conditions, appropriation is an alternative strategy to maintain survival. By creating the same "cultural language" as the dominant group, it is expected that Tenggerese (as the marginalized organic community) can negotiate for the sustainability of their existence. This is in line with what is stated by Aschroft et al. as follows.

"If globalism is not simply a result of top-down dominance but a transcultural process, a dialectic of dominant cultural forms and their appropriation, then the responses of local communities becomes critical. By appropriating strategies of representation, organization and social change through access to global systems, local communities and marginal interest groups can both empower themselves and influence those global systems." [5]

The closeness of Tayub culture to the life of Javanese people is a medium of dialogue for the Tenggerese to "communicate" their existence amid the constructs of Javanese culture in Ngadas. Tayub has become a middle ground to accommodate the needs of all Ngadas people in terms of social interactions. Identity negotiation by including Tayub in the Karo ritual is a logical and strategic choice in performing the ritual in Ngadas village. The dialogue between Tenggerese and Javanese are carried out in a space that allows related parties not to lose their cultural essences.

The development of culture is in line with the creativity of its bearers and supporters. In different words, Simmel said that "the cultural system and cultural creativity are attached to mutual interdependence and antagonistic nature" [11]. It means that the relationship between a cultural system and cultural creativity is like two separate sides of a coin which is, at the same time, united as a unit. Individuals and communities are attached in creating cultural reality. The hybridization as a medium of conformity plays an important role in putting together Tenggerese and Javanese culture. To be exact, Tayub is a medium of cultural negotiation between the two cultural entities resulting in the hybrid cultural construct in Ngadas village.

The two functions, educating and maintaining conformity, are management strategies that lead to the hybrid construction of Karo ritual in Ngadas village. It is a unique, creative, and effective communication mode of Tenggerese in Ngadas in the practical realm. It has also shown that Tenggerese in Ngadas village can survive in the dynamics of cultural interactions occurring in the village [12].

\section{CONCLUSIONS}

Karo ritual conducted by the Tenggerese in Ngadas village undergoes a change identified as a hybrid design that combines or incorporates Karo with one of the Javanese cultural features, Tayub dance, in the construction of Tenggerese sacred ceremony. The presence of this new feature serves two important functions. First, as an education system in the future for the Tenggerese inner circle in Ngadas village; that preservation of the Tengger's value system is not only done by maintaining doctrinal authenticity of a sacred ritual which is passed down from generation to generation but also by innovating the ritual accordingly as long as it does not violate the essential elements of the ritual. The second function is as an effort to maintain the conformity of the accepted cultural behavior in diverse cultural interactions existing in Ngadas village. Regarding the Tenggerese minority position in the cultural landscape of the village, this hybrid design is an effective form of cultural negotiation in maintaining their existence. The hybrid design allows Tenggerese to preserve its values and, at the same time, 
communicate the values to other cultural groups that live side by side with them. Thus, as a medium of communication, the design shows its ability to bridge the internal needs of its members and the needs of external parties.

\section{REFERENCES}

[1] Setiawan, F.N., Nurmansyah, M.A., Nufiarni, R. \& Eka S.V., "Manifestasi Kearifan Ekologis dalam Ritual Karo dan Kasada: Sebuah Perspektif Ekokritik," Atavisme, vol. 21, no. 2, pp 209-223, 2018

[2] Keto, "Personal Interview," October 15, 2016.

[3] Sims, M.C. \& Stephens, M., Living Folklore. Utah State University Press, 2005

[4] Purwadi, "Pentas Seni Tayub Sebagai Ritual Untuk Mendatangkan Kemakmuran," Jurnal Ikadbudi, vol. 6, no. 1, pp 94-100, 2017.

[5] Aschroft, B., Griffiths, G., \& Tiffin, H., Post-colonial Studies $2^{\text {nd }}$ edition. New York: Routledege. 2007.

[6] Tomo, "Personal Interview," October 8, 2016.

[7] Kamal, S., Saddhono, K., \& Suyitno, S., Cowongan is the Cultural Herritage of Banyumas: Relevance of Rituals as a Part of the Value Character Education," Proceedings of the 2nd Workshop on Language, Literature and Society for Education. 2019

[8] Kurniawan, A., Widodo, S., \& Saddhono, K., Happiness Value Inside Traditional Ceremony of Bagalan: Research on Communication Activities Ritual Wedding," Proceedings of the 2nd Workshop on Language, Literature and Society for Education. 2019

[9] Tyson, L., Critical Theory Today. New York: Routledge, 2006.

[10] Informant, "Personal Interview," October 15, 2017.

[11] Widyanta, A., Problem Modernitas dalam Kerangka Sosiologi Kebudayaan Georg Simmel. Yogyakarta: Cindelaras Pustaka Rakyat Cerdas. 2002.

[12] B.W. Setyawan and K. Saddhono, "Eret traditional ceremony as representation of spirit of mutual cooperation among coastal communities". Adv. Sci. Let. vol. 23 no.10, pp 9991-9992, 2017 